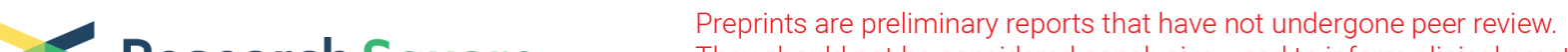 Research Square They should not be considered conclusive, used to inform clinical practice, or referenced by the media as validated information.
}

\section{Mechanisms generating the numerous hues of chrysanthemum petals can be traced to in vitro $Y-$ ray-induced mutagenesis.}

\section{Ambreena Din}

SKUAST Kashmir: Sher-E-Kashmir University of Agricultural Sciences and Technology Kashmir

\section{Zahoor Ahmed Qadri}

SKUAST Kashmir: Sher-E-Kashmir University of Agricultural Sciences and Technology Kashmir

MUNEEB AHMAD WANI ( $\square$ wanimuneeb05@gmail.com)

Sher-E-Kashmir University of Agricultural Sciences and Technology Kashmir https://orcid.org/00000002-7161-0901

\section{Z.A. Rather}

SKUAST Kashmir: Sher-E-Kashmir University of Agricultural Sciences and Technology Kashmir

\section{Shameen lqbal}

SKUAST Kashmir: Sher-E-Kashmir University of Agricultural Sciences and Technology Kashmir

\section{Sajid Ali Malik}

SKUAST Kashmir: Sher-E-Kashmir University of Agricultural Sciences and Technology Kashmir

\section{Sadaf Rafiq}

SKUAST Kashmir: Sher-E-Kashmir University of Agricultural Sciences and Technology Kashmir

\section{I.T. Nazki}

SKUAST Kashmir: Sher-E-Kashmir University of Agricultural Sciences and Technology Kashmir

\section{Research Article}

Keywords: Chrysanthemum, colour mutants, mutagenesis, gamma irradiation, mutants

Posted Date: November 22nd, 2021

DOI: https://doi.org/10.21203/rs.3.rs-617238/v2

License: (c) (i) This work is licensed under a Creative Commons Attribution 4.0 International License. Read Full License 


\section{Abstract}

In terms of global cut flower production, chrysanthemum (Dendranthemum grandiflorum kitam.) ranks among the top ten. When a plant species possesses colour characteristics associated with those of ancestral species, that colour is described as being white, yellow, or pink, with white coloration representing an absence of pigments, and yellow and pink coloration each represents the presence of carotenoids and anthocyanins, respectively. Pigments, or a combination of pigments, have been improved upon to provide an expansive rainbow of floral colours like orange, dark red, purplish-red, and red. Recent green-flowered varieties have developed a reputation for containing chlorophylls in their ray petals. Additionally, transgenic interventions have been used to breed violet/blue flowers. Flower colour is a highly regarded characteristic of any flower cultivar, particularly chrysanthemum. Breeders' ultimate goal is to create newer chrysanthemum cultivars with innovative characteristics, such as new flower colours, using a time and input-efficient approach. Investigating the molecular mechanisms that regulate flower pigmentation may yield critical insights into the rational manipulation of floral colour. To generate a diverse array of flower colour mutants in chrysanthemum cv. "Candid" through mutagenesis, in vitro grown micro shoots were exposed to 10,20,30, and 40 Gy gamma irradiation at 100 Gy per minute and were evaluated for different parameters. The rhizogenesis parameters declined with the increase in irradiation dose from $0 \mathrm{~Gy}$ to $40 \mathrm{~Gy}$, while as, $10 \mathrm{~Gy}$ dose proved to record minimum decline in contrast to the control. Survival, leaf size, and the number of leaves plant ${ }^{-1}$ after the $8^{\text {th }}$-week interval exhibited a downward trend with the increasing trend of gamma irradiation dose but recorded a least drop in plants raised from shoots irradiated with $10 \mathrm{~Gy}$ gamma irradiation dose with respect to the control. Apparently, the minimum delay in the number of days to floral bud appearance took under $10 \mathrm{~Gy}$ compared to control. The highest number of flower colour mutants was recorded under $10 \mathrm{~Gy}$ (light pink, orange-pink, white and yellow). Demountable mutation frequency based on flower colour was desirable in plants irradiated with the slightest dose of $10 \mathrm{~Gy}$.

\section{Introduction}

Chrysanthemum is a widely grown and indispensable cut flower crop in China, Japan, France, the United States of America, India, and the United Kingdom. It is a significant floricultural crop, ranking second in terms of cut flowers, after rose, among floricultural crops traded on the international flower market (Kumar et al. 2006). The complex genetic hetrozygosity makes the cultivated chrysanthemum an unlimited source of new flower form and cultivars. The common garden chrysanthemum is hexaploid with 54 chromosomes (Wolff 1996). It is propagated vegetatively and has a robust self-incompatibility system (Richards 1986); therefore, new varieties are complicated to acquire by crossing. Usually, new varieties have been developed from spontaneous mutations in vegetative reproduction, sports, being some variations more stable than others (Miñano et al., 2009). In recent years induced mutations along with the somaclonal variations resulting from the tissue culture practices have been in work as an innovative source of variability (Schum 2003, Datta et al. 2005, Jain et al. 2006, Zalewskam and Miller 2007, Chatterjee et al. 2006, Barakat et al. 2010) Even though comprehensive efforts have been 
undertaken to expand uniqueness in chrysanthemum cultivars by induced mutations employing physical and chemical mutagens (Broertjes and Van-Harten 1978), there is a constant need to investigate the chances of a new cultivars for horticulture trade. Mutation breeding by radiation has been extensively used to improve well-established plant cultivars and develop novel variants within superior consumer characteristics. While the majority of cultivated chrysanthemum varieties are polyploids with huge genetic heterogeneity, mutants with allied flower shape, floral size, and colour, are frequently recovered. Associated flower colours with chimeric tissue can be simply stimulated by radiation and isolated with in vitro apparatus (Kumar et al., 2006). Chrysanthemum is a hexaploid plant, and vegetative propagation (rather than sexual propagation) makes it difficult to carry out the hybridization, hence mutation processes are utilized (Broertjes and Van-Harten 1978). In any plant breeding programme, genetic variability is crucial for crop enhancement. In flower breeding, particularly for colour, mutation breeding is an efficient method of producing heritable change.

To create novel Chrysanthemum flower color/shape mutants, radiation has been used successfully (Misra et al. 2003; Dwimahyani and Widiarsih 2011). As a result, radiation-induced mutagenesis has become a critical approach for flower breeding. When observable characteristics such as flower colour, shape, and size, or leaf structure and growth habit are considered, the selection of ornamentals is quite simple. By 2005, 2,335 varieties were released through mutagenesis in the world, in which ornamental and decorative crops were 552 (IAEA 2005). However, the main bottleneck is formation of chimera, which appears after physical mutagen treatment. The uses of in vitro mutagenesis for development of solid mutant were previously reported by Latado et al. (2004) and Chakrabarty et al. (1999). The mutant sector can range in size from a thin streak on a petal to the entire flower in chimeric tissues. When a petal or an entire flower is mutated, the mutant tissue can be extracted and studied. On the other hand, using normal replication techniques, a small segment of a mutant blossom cannot be separated. As a result, many novel flower colour/shape mutants caused by mutagens are lost due to the absence of a system for regeneration from small-mutated sectors in vivo or in vitro. Thus, the ability to regenerate plants from single floret cells would be an advantageous strategy for establishing mutants in pure form from chimaeras and for facilitating the generation of a diverse range of unique cultivars with innovative flower colours and shapes.

The assumption was made for a good mutation breeding programme; there are numerous considerations to bear in mind. These include the sort of genetic material, the traits to be enhanced, the type of mutagens, and their dosage to be utilised, as well as an experimental procedure to choose. The hypothesis goes further, asserting that this method for inducing variation, called mutation breeding, makes it possible to produce genetic diversity that is both statistically and qualitatively meaningful in the programme. In the study of mutation and variability, researchers were able to come up with a novel chrysanthemum cultivar with a highly anticipated customer appeal. As a result of the foregoing, the current study was undertaken with the goal of generating a diverse array of flower colour mutants via mutagenesis. 


\section{Materials And Methods}

The current study was carried out in plant tissue culture laboratory at the Department of Floriculture and Landscape Architecture SKUAST-Kashmir. Tissue culture developed micro shootlets of chrysanthemum cv. 'Candid' (parent cultivar, Figure-1) were exposed to Cobalt ${ }^{60}$ gamma irradiation doses of $0,10,20,30$, and 40 Gy at 100 Gy per minute and were allowed to raise vegetatively mutated generations first and second at 5-week intervals. Finally, shoots obtained from vegetatively mutated generation 2 were allowed for rooting and consequent acclimatization. Rooted shoots were allowed to grow in pots in the field to obtain new enviable colour mutants, and rooting parameters were recorded in terms of percentage rooting and the number of roots per shoot. Survival (\%), leaf area plant ${ }^{-1}\left(\mathrm{~cm}^{2}\right)$, number of leaves plant ${ }^{-1}$ were recorded at $4^{\text {th }}$ and $8^{\text {th }}$ weeks growth in the field. Days to flower bud appearance were recorded at the initiation of flower bud appearance. Plant height was noted at the end of full flower bloom. Flower colour was recorded in terms of the difference between the parent flower and mutants obtained. The frequency of mutation was calculated based on flower colour, as the ratio between such desired or undesired colour mutant and whole plants irradiated with each gamma irradiation dose.

The investigation used a completely randomised design with four replications, and the data were analysed using analysis of variance after being compiled from various trail observations (ANOVA). To ensure that the model assumptions for ANOVA were met, percent age data were transformed using the square root method recommended by Steel and Torrie (1980), and the average data were classified using Duncan's multiple range test. (Gomez \& Gomez, 1983).

\section{Results}

\subsection{Effect of gamma irradiation on rhizogenesis}

Data pertaining to the effect of ${ }^{60} \mathrm{Co}$ gamma irradiation on rooting per cent and root number of chrysanthemum (Dendranthemum morifolium L.) cv. "Candid" have been presented in Table 1. It is quite vivid from the data that irradiation doses had enervating effect on all the parameters of rooting in comparison to control (Fig.6a and 6b). Perusal of data reveal that there was a significant decrease in mean rooting per cent in all the irradiation treatments in comparison to control shoots $(89.28 \%)$. Among irradiation treatments maximum (85.71\%) rooting was recorded under $10 \mathrm{~Gy}$ dose, representing only 1.90 per cent decrease in rooting in comparison to control. This treatment dose was followed by 20 Gy $(79.76 \%)$ and $30 \mathrm{~Gy}(74.99 \%)$, corresponding to 5.40 and 8.26 per cent decrease over control, respectively. Both the treatments varied significantly different from each other. Further perusal of data reveal that highest dose $40 \mathrm{~Gy}$ of ${ }^{60} \mathrm{Co}$ gamma irradiation resulted significantly minimum 73.80 per cent rooting, corresponding to a heavy decrease $(9.00 \%)$ in rooting over control (Figure 2a and $2 b$ ). There was significant differences in mean root number 7.75 and 15.75 shoot $^{-1}$ recorded under 10 Gy dose and control, respectively. Under higher doses of 20,30 and $40 \mathrm{~Gy}$, root number significantly dropped to 5.50 , 
3.00 and 2.75 shoot $^{-1}$, respectively. Correlation analysis of number of root per shoot showed a significant relation with the induction of rooting percentage (Figure 3 ).

Table 1: Influence of ${ }^{60} \mathrm{Co}$ gamma irradiation on rhizogenesis in shoots of Chrysanthemum (Dendranthemum morifolium L.) cv. "Candid"

\begin{tabular}{|c|c|c|}
\hline Dose & Rooting (\%) & Root number \\
\hline 0 Gy & $89.28 \mathrm{a} \pm 2.38$ & $\begin{array}{c}15.75 a \pm 0.50 \\
-\end{array}$ \\
\hline $10 \mathrm{~Gy}$ & $85.71 \mathrm{~b} \pm 0.00$ & $\begin{array}{r}7.75 \mathrm{~b} \pm 0.96 \\
(50.79) * *\end{array}$ \\
\hline $20 \mathrm{~Gy}$ & $79.76 \mathrm{c} \pm 2.38$ & $\begin{array}{rr}5.50 & \mathrm{C} \pm 0.58 \\
& \\
& (65.07)\end{array}$ \\
\hline $30 \mathrm{~Gy}$ & $74.99 \mathrm{~d} \pm 2.38$ & $\begin{array}{r}3.00 \mathrm{~d} \pm 0.00 \\
(80.95)\end{array}$ \\
\hline $40 \mathrm{~Gy}$ & $\begin{array}{l}(8.59) \\
(9.00)\end{array}$ & $2.75 d \pm 0.50$ \\
\hline L.S.D ${ }_{P \leq 0.05}$ & 0.18 & 0.90 \\
\hline
\end{tabular}

*Figures in the parenthesis are the square root transformed values of percentage data **Figures in the parenthesis are the per cent decrease in vegetative parameters over control

\subsection{Effect of gamma irradiation on survival of rooted plantlets under polyhouse conditions}

Data recorded on survival of rooted plantlets of chrysanthemum (Dendranthemum morifolium L.) cv. "Candid" at the end of 4 and 8 weeks under polyhouse conditions have been presented in Table 2.Perusal of data reveal that survival of rooted plantlets declined with each increment of gamma dose in both the intervals of $4^{\text {th }}$ and $8^{\text {th }}$ week. In cv. "Candid" survival of rooted shoots was significantly minimum (85.71\%) with 10 Gy dose as against 95.23 per cent in control at the end of the 4 weeks (Fig. 6c). It further decreased to $76.18,61.90$ and 53.56 per cent, respectively with 20,30 and 40 Gy radiation doses. Latter treatment corresponded to 25.10 per cent decrease of survival over control. In second interval (i.e., after 8 weeks) survival of 82.14 per cent recorded under $10 \mathrm{~Gy}$ dose was significantly decreased in comparison to 95.23 per cent in control(Fig. 6d). This treatment was followed by $20 \mathrm{~Gy}(67.85 \%)$ and $30 \mathrm{~Gy}(53.56 \%)$ doses. Microshoots exposed to 40 Gy dose significantly decreased survival to 40.47 per cent, corresponding to 35.04 per cent decline in comparison to control. Also strong correlation was found between survival percentage and dosage (Figure. 4).

Table 2: Influence of ${ }^{60} \mathrm{Co}$ gamma irradiation on survival of rooted plantlets under polyhouse conditions in Chrysanthemum (Dendranthemum morifolium L.) cv. "Candid" 


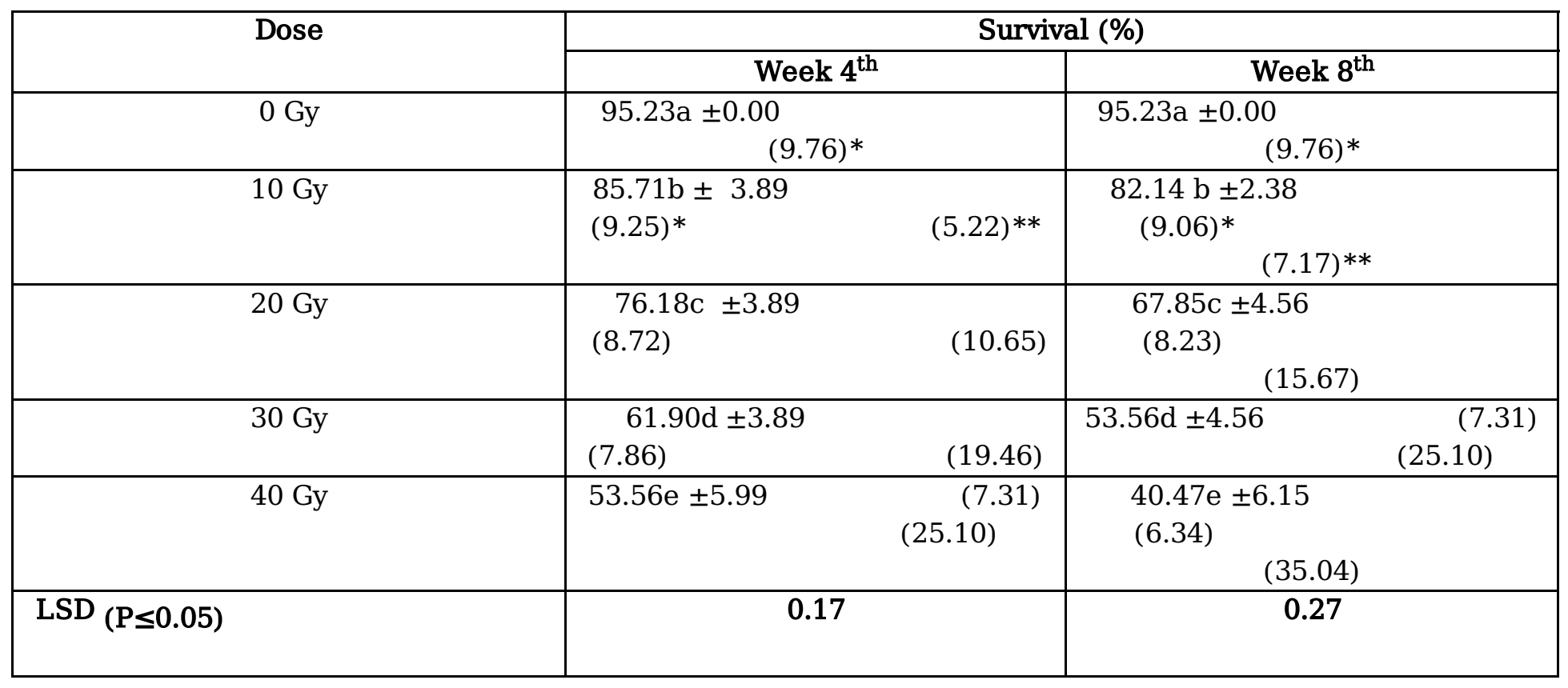

*Figures in the parenthesis are the square root transformed values of percentage data **Figures in the parenthesis are the per cent decrease in vegetative parameters over control

\subsection{Effect of gamma irradiation on leaf number and leaf size}

Data regarding the effect of ${ }^{60} \mathrm{Co}$ gamma irradiation on leaf number and leaf size of chrysanthemum (Dendranthemum morifolium L.) cv. "Candid" at 4 and 8 week intervals are presented in Tables 3. In cv. "Candid" there was a marginal decline in leaf number under $10 \mathrm{~Gy}\left(11.00\right.$ plant $\left.^{-1}\right)$ and $20 \mathrm{~Gy}\left(9.25\right.$ plant $\left.^{-1}\right)$ at the end of 4 weeks as compared to control $\left(14.00\right.$ plant $\left.^{-1}\right)$. Leaf number with 30 and 40 Gy doses decreased to 8.75 and 8.00 plant $^{-1}$, respectively. These results were statistically at par with each other. The corresponding decline in these results was 37.50 and 42.85 per cent respectively in comparison to control. At the end of 8 weeks mean leaf number in 10 and 20 Gy treatments marginally decreased to 13.00 and 11.75 plant $^{-1}$ respectively in comparison to control ( 15.75 leaves plant $\left.{ }^{-1}\right)$. It further decreased to 10.75 and 9.75 leaves plant ${ }^{-1}$ under 30 and 40 Gy doses, respectively. These treatments corresponded to a decline of 31.74 and 38.09 per cent number of leaves over control, respectively (Fig.6e and 6f).Further perusal of data, reveal that radiation treatments had significant effect on leaf size recorded at the end of 4 and 8 weeks interval. At the end of $4^{\text {th }}$ week, maximum leaf size of $22.30 \mathrm{~cm}^{2}$ plant $^{-1}$ was recorded in control plants which marginally decreased to $20.42 \mathrm{~cm}^{2}$ under $10 \mathrm{~Gy}$ dose, followed by $20 \mathrm{~Gy}$ $\left(17.34 \mathrm{~cm}^{2}\right)$. With the exposure of 30 and $40 \mathrm{~Gy}$ of plants, leaf size significantly declined to 13.52 and $5.31 \mathrm{~cm}^{2}$ plant $^{-1}$, respectively. Both the treatments were statistically different from each other. These results corresponded to 39.37 and 76.18 per cent decrease of leaf size against control. At the end of $8^{\text {th }}$ week, leaf size per plant improved under gamma irradiation treatments. While, 10 and 20 Gy treatments decreased leaf size marginally to 27.80 and $20.42 \mathrm{~cm}^{2}$ plant $^{-1}$, respectively in comparison to control $\left(28.52 \mathrm{~cm}^{2}\right)$, the decline in 30 and $40 \mathrm{~Gy}$ doses was significant. These treatments recorded leaf size of 
14.82 and $10.74 \mathrm{~cm}^{2}$ plant ${ }^{-1}$ respectively, which corresponded to 48.03 and 62.34 per cent decrease over control (Figure $6 \mathrm{~g}$ and $6 \mathrm{~h}$ ).

Table 3: Influence of ${ }^{60} \mathrm{Co}$ gamma irradiation on leaf number and leaf size in Chrysanthemum (Dendranthemum morifolium L.) cv. "Candid"

\begin{tabular}{|c|c|c|c|c|}
\hline \multirow[t]{2}{*}{ Dose } & \multicolumn{2}{|c|}{ Leaf number plant ${ }^{-1}$} & \multicolumn{2}{|c|}{ Leaf size (length/width) } \\
\hline & $4^{\text {th }}$ week & $8^{\text {th }}$ week & $4^{\text {th }}$ week & $8^{\text {th }}$ week \\
\hline $0 \mathrm{~Gy}$ & $14.00 \mathrm{a} \pm 0.82$ & $15.75 a \pm 0.96$ & $22.31 \mathrm{a} \pm 3.30$ & $28.52 \mathrm{a} \pm 1.18$ \\
\hline $10 \mathrm{~Gy}$ & $\begin{array}{r}11.00 \mathrm{~b} \pm 0.82 \\
(21.42)\end{array}$ & $\begin{array}{r}13.00 \mathrm{~b} \pm 0.82 \\
(17.46)\end{array}$ & $\begin{array}{r}20.42 \mathrm{a} \pm 1.45 \\
(8.43)\end{array}$ & $\begin{array}{r}27.80 \mathrm{a} \pm 0.89 \\
(2.52)\end{array}$ \\
\hline $20 \mathrm{~Gy}$ & $\begin{array}{rr}9.25 & \mathrm{C} \pm 0.50 \\
& (33.92)\end{array}$ & $\begin{array}{r}11.75 \text { bc } \pm 0.96 \\
(25.39)\end{array}$ & $\begin{array}{r}17.34 \mathrm{~b} \pm 01.32 \\
(22.24)\end{array}$ & $\begin{array}{r}20.42 \mathrm{~b} \pm 1.45 \\
(28.40)\end{array}$ \\
\hline $30 \mathrm{~Gy}$ & $\begin{array}{rr}8.75 & \mathrm{~cd} \pm 0.50 \\
& (37.50)\end{array}$ & $\begin{array}{r}10.75 \mathrm{~cd} \pm 0.96 \\
(31.74)\end{array}$ & $\begin{array}{cc}13.52 & \mathrm{c} \pm 0.72 \\
& (39.37)\end{array}$ & $\begin{array}{r}14.82 \mathrm{c} \pm 1.23 \\
(48.03)\end{array}$ \\
\hline $40 \mathrm{~Gy}$ & $\begin{array}{rr}8.00 & d \pm 0.00 \\
& (42.85)\end{array}$ & $\begin{array}{ll}9.75 & \mathrm{~d} \pm 0.96 \\
& (38.09)\end{array}$ & $\begin{array}{cc}5.31 & d \pm 0.66 \\
& (76.18)\end{array}$ & $\begin{array}{r}10.74 \mathrm{~d} \pm 2.14 \\
(62.34)\end{array}$ \\
\hline L.S.D ${ }_{P \leq 0.05}$ & 0.92 & 1.41 & 2.69 & 2.37 \\
\hline
\end{tabular}

Figures in the parenthesis are the per cent decrease in vegetative parameters over control

\subsection{Effect of gamma irradiation on number of days to floral bud appearance and plant height at flowering}

Data regarding the effect of gamma irradiation on number of days to flower bud appearance and plant height at flowering in chrysanthemum (Dendranthemum morifolium L.) cv. "Candid" are presented in Table 4. In cv. "Candid" regarding days to flower bud appearance, perusal of data, reveal that with the increment of each dose of irradiation there was a significant increase in days to bud appearance in comparison to control plants (23.50). Under 10, 20 and $30 \mathrm{~Gy}$ doses days to bud appearance was recorded $27.25,37.00$ and 39.25 , respectively. These treatment doses were significantly different among themselves and corresponded to an increase of $15.95,57.44$ and 67.02 per cent over control. Whereas, days to bud appearance under last dose of $40 \mathrm{~Gy}$ was recorded significantly highest 40.75 , which represented highest increase of 73.40 per cent when compared to control. Regarding plant height at flowering, perusal of data, reveal that with the increment of each dose of irradiation there was a significant decrease in plant height in comparison to control plants $(53.25 \mathrm{~cm})$. Under 10, 20 and $30 \mathrm{~Gy}$ doses plant height was recorded $49.00,36.50$ and $34.00 \mathrm{~cm}$, respectively. These treatment doses were significantly different among themselves and corresponded to a decrease of $7.98,31.45$ and 36.15 per cent over control. Whereas, plant height at flowering time under last dose of $40 \mathrm{~Gy}$ was recorded significantly lowest $31.50 \mathrm{~cm}$, which represented highest decrease of 40.84 per cent when compared to control (Figure 6i). 
Table 4: Influence of ${ }^{60} \mathrm{Co}$ gamma irradiation on the number of days to floral bud appearance and plant height at flowering in Chrysanthemum (Dendranthemum morifolium L.) cv. "Candid"

\begin{tabular}{|c|c|c|}
\hline Dose & Number of days to floral bud appearance & Plant height at flowering(cm) \\
\hline $0 \mathrm{~Gy}$ & $23.50 \mathrm{a} \pm 1.73$ & $53.25 \mathrm{a} \pm 2.50$ \\
\hline $10 \mathrm{~Gy}$ & $27.25 \mathrm{~b} \pm 1.50$ & $49.00 \mathrm{~b} \pm 0.82$ \\
& $(15.95)$ & $(7.98)$ \\
\hline $20 \mathrm{~Gy}$ & $37.00 \mathrm{c} \pm 0.82$ & $36.50 \mathrm{c} \pm 0.58$ \\
& $(57.44)$ & $(31.45)$ \\
\hline $30 \mathrm{~Gy}$ & $39.25 \mathrm{~cd} \pm 1.89$ & $34.00 \mathrm{~d} \pm 20.82$ \\
& $(67.02)$ & $(36.15)$ \\
\hline $40 \mathrm{~Gy}$ & $40.75 \mathrm{~d} \pm 2.22$ & $31.50 \mathrm{e} \pm 1.00$ \\
& $(73.40)$ & $(40.84)$ \\
\hline L.S.D $\mathbf{P} \leq \mathbf{0} \mathbf{0 5}$ & $\mathbf{2 . 5 8}$ & $\mathbf{2 . 0 3}$ \\
\hline
\end{tabular}

Figures in the parenthesis represent per cent increase in case of days to floral bud appearance and per cent decrease in plant height at flowering over control

\subsection{Effect of gamma irradiation on flower colour and mutation frequency}

Regarding the effect of gamma irradiation on flower colour, desired colour mutants were selected only from the plants irradiated with $10 \mathrm{~Gy}$ dose, which evolved 60 per cent of light pink, 15 per cent of orangepink, 10 per cent white, 5 per cent light yellow (5\%) and remaining 10 per cent were as same as control i.e., showing original red colour (Fig.5 a, 5b, 5c and 5d). Higher doses of 20, 30 or 40 Gy produced either distorted red bud or distorted red floret (Fig.5e and 5f).Colour mutants under 20, 30 and 40 Gy were undesirable. Data regarding the mutation frequency in chrysanthemum flowers on the basis of flower colour, there was a highly desired mutation frequency amounting to 90 per cent when the plants were irradiated with $10 \mathrm{~Gy}$ dose. Whereas, under 20,30 and 40 Gy doses flower mutation frequency although recorded cent per cent, but produced undesirable mutants.

\section{Discussion}

\subsection{Effect of gamma irradiation on rhizogenesis}

It is quite vivid from the data (Table 1), that irradiation doses had enervating effect on all the parameters of rooting in comparison to control. Perusal of data revealed that there was a significant decrease in mean rooting per cent and number of roots shoot ${ }^{-1}$ in all the irradiation treatments in comparison to control. Among irradiation treatments maximum rooting and number of roots were recorded under 10 Gy dose, followed by 20 and $30 \mathrm{~Gy}$ irradiation doses. Minimum rooting and number of roots were registered with $40 \mathrm{~Gy}$ dose. Rhizogenesis in vitro involves development of roots de novo. It is a process of dedifferentiation of specific pre-determined cells near the vascular bundles. Any damage to cell division ability will have a negative effect on dedifferentiation of cells and subsequent reorganization into root primordia. This may result in failure of rooting or delayed emergence of roots. Singh et al. (1999), also reported that increased doses of gamma irradiation (from 20 to $50 \mathrm{~Gy}$ ) decreased rooting percentage of 
carnation cv. 'Espana'. Radiation treatments also delayed root initiation significantly in comparison to control. Sooch et al. (2000), observed delayed root initiation of carnation shoots of cv. 'Scania' under $1.00,1.50$ and $2.00 \mathrm{~K}$-rads gamma irradiation doses. The deleterious effects of radiations were also reflected in significant decline in root number shoot ${ }^{-1}$ under 10 to $30 \mathrm{~Gy}$ treatments. El-sharnouby and ElKhateeb (2005), also reported that most of the gamma irradiation treatments (10, 20, 30 and $40 \mathrm{~Gy}$ ) without or with NAA in the rooting medium decreased the number and the length of roots in the carnation cultivars "Medea", "Candela" and "Picaro". All the above quoted studies are in close conformity with the observations recorded in the present study.

\subsection{Effect of gamma irradiation on survival of rooted plantlets}

Perusal of data (Table 2), reveal that survival of rooted shoots at the end of 4 week was significantly minimum by the shoots treated with $40 \mathrm{~Gy}$ dose as against control, followed by 30 and $20 \mathrm{~Gy}$ dose. Under minimum dose of $10 \mathrm{~Gy}$, there was a minimum decline in survival of shoots at the end of the 4 week over control. At the end of 8 week, shoots treated with 10 Gy dose recorded maximum survival, followed by 20 and $30 \mathrm{~Gy}$ dose. While as, lowest survival per cent was recorded in shoots treated with $40 \mathrm{~Gy}$ dose corresponding to heavy decline in comparison to control. Broertjes and De-Jong (1984), obtained 100\% survival when chrysanthemum plantlets transferred to soil were irradiated with 2.5 or $5 \mathrm{kGy}$. Major reason for mortality in post irradiation propagation generations is due to deleterious chimera load carried by the plants. The impaired cells or tissue sectors on coming to occupy significant portions of growing point lead to death or debilitated plants which do not survive more exacting environmental demands in the field. Any impairment in the epidermal skin of the plants gets quickly exposed in the field leading to mortality. Another reason might be formation of low or reduced wax component on the post irradiation plants. As the wax component determines the rate of water loss through the cuticle and the susceptibility of tissue-cultured plants to desiccation attributed to a reduction or absence of wax acting as antitranspirant. The epicuticular wax is reduced or absent on the carnation leaves of in vitro cultured plants compared to glasshouse or field-grown plants (Sutter and Langhans, 1979), but during acclimatization, the density of waxes increases as the humidity is lowered (Wardle et al., 1983). Since the irradiation impairs the epidermal skin of the plants leading to low wax formation even during the acclimatization process, hence any impairment in the epidermal surface of the plants gets quickly exposed in the field or polyhouse leading to mortality. This finding is in accordance to the results in present investigation.

\subsection{Effect of gamma irradiation on leaf number and leaf size}

In cv. "Candid", perusal of data (Table 3) reveal that gamma irradiation treatments significantly recorded a decline in leaf number plant ${ }^{-1}$ and leaf size in both the intervals i.e., 4 and 8 week as compared to control. At the end of 4 week, significantly minimum leaf number plant ${ }^{-1}$ and size was registered under highest dose of $40 \mathrm{~Gy}$, followed by 30 and $20 \mathrm{~Gy}$ and the lowest gamma irradiation dose $10 \mathrm{~Gy}$ recorded a minimum decrease in leaf number and size, as compared to the control. At the end of 8 week, both leaf number as well as leaf size improved in all the gamma irradiation doses including the control plants but 
recorded the similar trend of decline in both the parameters as in the 4 week interval with the successive gamma irradiation doses. Increase in leaf area is a function of the expansion of leaf cells which depends upon the acid growth driven elasticity of cell walls mainly controlled by auxins. Irradiation is known to disturb auxin synthesis and distribution patterns (Gordon, 1956). This may be the reason for poor expansion of leaf surface and hence lower leaf area due to high irradiation exposure. Several workers have reported decline in leaf area in many flower species as a result of irradiation (Gupta et al., 1974 in tuberose; Misra and Bajpai, 1983 in gladiolus; Gupta et al., 1982 in costus; Siranut et al., 2000 in chrysanthemum). Kahrizi et al. (2011), in rose and Srivastava et al. (2007), in gladiolus also reported the decrease in number of leaves with the increase in dosage of gamma irradiation. They further reported that there was no significant effect of $10 \mathrm{~Gy}$ dose on leaf size explant ${ }^{-1}$, however 20 to $40 \mathrm{~Gy}$ irradiation significantly reduced leaf size plant ${ }^{-1}$ recorded at the end of two intervals. Inhibitory effect of gamma rays on vegetative characters of carnation at higher doses has also been observed by Acharya and Tiwari (1996). In another study Simard et al. (1992) and Cassels et al. (1993), recorded biological damage in carnation on increasing the dose of radiation. Misra et al. (2009), in chrysanthemum have also reported decline in leaf area as a result of irradiation whereas, Kumari et al. (2013), reported reduction in leaf size in terms of length and width of plants treated with higher doses of gamma rays in variety "Otome Pink". They found that petiole length was shorter with increasing dose of mutagenic agents. All mutagenic agents decreased the leaf area over the control, except 0.5 gamma rays. Reduction in leaf area was observed with increasing dose of mutagens. Mahure et al. (2010), recorded that lower doses like 10 and 20 Gy increased leaf area but 30 Gy decreased leaf area over control. In yet another study by Dilta et al. (2006), rreduction in leaf number was reported in Dandranthema morifolium cv. "Gulmohar" under 1.0, $1.5,2.0,2.5$ and $3 \mathrm{kR}$ of gamma irradiation. All the above quoted studies are in concurrence with the findings recorded in the present study.

\subsection{Days to floral bud appearance and Plant height $(\mathrm{cm})$ at flowering.}

In cv. "Candid" regarding days to bud appearance, perusal of data (Table 4) reveal that with the increment of each dose of irradiation there was a significant increase in days to bud appearance in comparison to control plants (23.50). Under 10, 20 and 30 Gy doses days to bud appearance was recorded 27.25, 37.00 and 39.25 , respectively. Whereas, days to bud appearance under last dose of $40 \mathrm{~Gy}$ was recorded significantly highest 40.75 , which represented highest increase as compared to control. The results in the present study may be due to the disturbances in biochemical pathway which assists in synthesis of flower inducting substances and hence delay in flowering. The results in the present study are in concurrence with the findings of Datta and Banerji (1993), who observed delayed flowering behaviour after irradiating rooted cutting of small decorative type chrysanthemum cv. "Kalyani Mauve". In another study Dilta et al. (2003), also observed significant delay in days to bud formation, buds showing colour and days for full bloom in the treated plants of ten chrysanthemum cultivar as compared to control. Similar were the results obtained by Misra et al. (2009) in chrysanthemum cv. "Pooja". Plant height is genetic characteristics of the plants and it was expressed as per the individual potential of variety. Regarding plant height at flowering, perusal of data (Table 4) reveal that with the increment of each dose 
of irradiation there was a significant decrease in plant height in comparison to control plants $(53.25 \mathrm{~cm})$. Under 10, 20 and 30 Gy doses plant height was recorded $49.00,36.50$ and $34.00 \mathrm{~cm}$, respectively. Whereas, plant height at flowering time under last dose of $40 \mathrm{~Gy}$ was recorded significantly lowest 31.50 $\mathrm{cm}$, which represented highest decrease as compared to control. Reduction in vegetative characters by gamma rays treated plants depends on the nature and extend of chromosomal damage or due to physiological, morphological and cytological disturbance caused by irradiation. Also due to the reduction of internal auxin production which leads to reduction of growth of plant (Singh et al., 2011). Also due to the inactivation and decrease in auxin synthesis and nature and extent of chromosomal aberration (Dilta et al., 2003). The results in the present study are in concurrence with the findings of Banerji and Datta $(1992,2002)$, who observed decrease in plant height with increased dose of gamma irradiation in rooted cutting of chrysanthemum cv. "Jaya" and "Lalima". Kole and Meher (2005), also reported decreasing effects in zinnia might be due to physiological damage caused by mutagen at higher doses.

\subsection{Flower colour and Mutation Frequency}

Regarding the colour of flowers after irradiation, desired colour mutants were selected only from the plants irradiated with $10 \mathrm{~Gy}$ dose, which evolved 60 per cent of pink, 15 per cent of orange pink, 10 per cent white, 5 per cent light yellow (5\%) and remaining 10 per cent were as same as control i.e., showing original red colour. Higher doses of 20,30 or 40 Gy produced either distorted red buds or distorted red. Colour mutants under 20,30 and 40 Gy were undesirable. The results in the present study may be due to physiological changes which occur in plant, hence, delayed flowering occur at higher doses due to inhibitory effect. This can be attributed to the fact that no chimeric growth was developed in shoot as result of mutagenesis. Shoot or tissue without chimeric growth lead to non-formation, different colour variation in petals reported by Longton (1980) in chrysanthemum. This quoted observation is in close conformity to the present study

Data regarding the mutation frequency in chrysanthemum flowers on the basis of flower colour, there was a highly desired mutation frequency amounting to 90 per cent when the plants were irradiated with 10 Gy dose. Whereas, under 20,30 and 40 Gy doses flower mutation frequency although recorded cent per cent, but produced undesirable mutants. The results obtained in the present study are in accordance to the finding of Siavash et al. (2009), who reported increase in mutation frequency when plants were UV irradiated.

\section{Conclusion}

The study found that a 40-Gy dose of irradiation resulted in a significant decrease in the percentage of rooting, which led to a subsequent decrease in the survival rate of the plant in the field. It also found that plants didn't grow as high as they normally would, that the period of time between bud emergence and flowering was delayed, and that mutation frequencies were also lower. With regard to flower colour, Light pink, Orange-Pink, White, and yellow were the most preferred mutants, while their mutation frequency was 
highest when the sample was irradiated with $10 \mathrm{~Gy}$. Additionally, the treatment of $10 \mathrm{~Gy}$ with gamma rays is suitable for mutagenesis in Chrysanthemum Cv. "Candid".

\section{Declarations}

\section{Acknowledgements}

Sincere thanks to UGC, Gol for doctoral fellowship during the course of programme.

\section{Conflict of interest}

No conflict of interest.

\section{References}

Acharya, N.N \& Tiwari D.S. Effect of MMS and gamma rays on seed germination, survival and pollen fertility of Hamatocactus setispinus in $\mathrm{M}_{1}$ generation. Mysore Journal of Agricultural Science. 3(1), 10-13 (1996).

Banerji, B.K \& Datta, S.K Gamma ray induced flower shape in chrysanthemum cv. 'Jaya'. Journal of Nuclear Agriculture and Biology., 21(2), 73-79 (1992).

Banerji, B.K \& Datta, S.K. Induction and analysis of gamma ray-induced flower head shape mutation in 'Lalima chrysanthemum (Chrysanthemum morifolium). Indian Journal of Agricultural Science., 72, 6-10 (2002).

Barakat, M.N., Abdel, F.R.S., Badr, M \& El-Torky, M.G. In-vitro culture and plant regeneration derived from ray florets of Chrysanthemum morifolium. African Journal of Biotechnology 9(8), 1151-1158 (2010).

Broertjes, C \& De-Jong, J. Radiation induced male sterility in daisy type of Chrysanthemum morifolium Ramat. Euphytica. 33,433-34 (1984).

Broertjes, C \& Van-Harten, A.M. Application of mutation breeding methods in the improvement of vegetatively propagated crops. An interpretive literature review In: Developments in crop science (2). (Elsevier Scientific Publishing Company, Amsterdam pp. 316 1978).

Cassels, A.C., Walsh, C \& Periappuram, C. Diplontic selection as a positive factor in determining the fitness of mutants of Dianthus 'Mystere derived from X-irradiation of nodes in in vitro culture. Euphytica.. 70, 167-174 (1993).

Chakrabarty D, Mandal A, Datta S. Management of chimera through direct shoot regeneration from florets of chrysanthemum (Chrysanthemum morifolium Ramat.). J of hortic sci biotechnol 74(3):293-296 (1999). 
Chatterjee, J., Mandal, A.K.A., Ranade, SA \& Teixeira da Silva, J.A. Datta SK. Molecular systematics in Chrysanthemum x grandiflorum (Ramat.) Kitamura. Scientia Horticulturae 110, 373-378 (2006)

Datta, S.K \& Banerji, B.K. Gamma ray induced somatic mutation in chrysanthemum cv. 'Kalyani Mauve'. Journal of Nuclear Agricultural Biology. 22, 58-61 (1993).

Datta SK, Misra P, Mandal AKA. In-vitro mutagenesis a quick method for establishment of solid mutant in chrysanthemum. Current Science. 88(1), 155-158 (2005).

Dilta, B.S., Sharma, Y.D., Dhiman, S.R \& Verma, V.K. Induction of somatic mutations in chrysanthemum by gamma irradiation. International Journal of Agricultural Sciences., 2(1), 77-81 (2006).

Dwimahyani I, Widiarsih S. The effects of gamma irradiation on the growth and propagation of in-vitro chrysanthemum shoot explants (cv. Yellow Puma). Atom Indonesia 36 (2) (2011).

El-Sharnouby, M.E \& El-Khateeb, M.A.A. Effect of BA, NAA and gamma irradiation on the production of three cultivars of carnation (Dianthus caryophyllus L.) through tissue culture. Annals of Agricultural Science, Moshtohor. 43(4), 1937-1948 (2005).

Gomez, K.A \& Gomez, A.A. Statistical Procedures for Agricultural Research. (Wiley-Interscience Publications, New York pp. 84 1983).

Gupta, M.N., Laxmi, V., Dixit, B.S \& Srivastava, S.N. Gamma rays induced variability in Costus speciosus. Progressive Horticulture, 14,193-197 (1982).

Gupta, M.N., Sumiran, R \& Shukla, R. Mutation breeding of tuberose Polianthus tuberosa L. In: Proceedings of the Symposium on Use of Radiations and Radio Isotopes in Studies of Plant Productivity. 12-14, 169-179 (1974).

Jain, S.M. Mutagenesis in crop improvement under the climate change. Romanian Biotechnological Letters. 15, 88-106 (2010)

Kahrizi, Z.A., Kermani. M.J., Amiri, M.E \& Vedadi, S. Identifying the correct dose of gamma-rays for in vitro mutation of rose cultivars. In: Acta Horticulturae (Eds. A. Fabbri and E. Rugini) Proceedings of the XXVIIIth International Horticultural Congress on Science and Horticulture International Symposium on Micro and Macro Technologies for Plant Propagation and Breeding in Horticulture 923, 121-127 (2011).

Kole, P.C, \& Meher, S.K. Effect of gamma rays of some quantitative and qualitative characters in zinnia (Zinnia elegans $\mathrm{N}$. J Jacquin) in $\mathrm{M}_{1}$ generation. Journal of Ornamental Horticulture, 8(4), 303-305 (2005).

Kumar, S., Prasad, K.V \& Choudhary, M.L. Detection of genetic variability among chrysanthemum radio mutants using RAPD markers. Current Science. 90, 1108-1113 (2006) 
Kumari, K., Dhatt, K \& Kapoor, M. Induced mutagenesis in Chrysanthemum morifolium variety 'Otome Pink'through gamma irradiation. Bioscan., 8, 1489-1492 (2013).

Langton, F.A. Chimerical structure and carotenoid inheritance in Chrysanthemum morifolium (Ramat.). Euphytica. 29, 807-812 (1980)

Latado R, Herna'n Adames A, Tulmann Neto A. In vitro Mutation of Chrysanthemum (Dendranthema grandiflora Tzvelev) with Ethylmethanesulphonate (EMS) in Immature Floral Pedicels. Plant Cell, Tissue Organ Cult77(1):103-106. (2004). doi:10.1023/b:ticu.0000016481.18358.55

Mahure, H.R., Choudhry, M.L., Prasad, K.V \& Singh, S.KMutation in chrysanthemum through gamma irradiation. Indian Journal of Horticultural., 67, 356-358 (2010).

Miñano, H.S., González-Benito, M..E \& Martin, C. Molecular characterization and analysis of somaclonal variation in chrysanthemum cultivars using RAPD markers. - Sci. Hort., 122, 238-243 (2009)

Misra P, Datta S, Chakrabarty D. Mutation in flower colour and shape of Chrysanthemum morifolium induced by c-radiation. Biol Plant 47(1):153-156 (2003).

Misra, P., Banerji, B.K \& Kumari, A. Effect of gamma irradiation on chrysanthemum cultivar 'Pooja with particular reference to induction of somatic mutation in flower colour and form. Journal of Ornamental Horticulture., 12, 213-216 (2009).

Misra, R.L \& Bajpai, P.N. Mutational studies in gladioli (Gladiolus) I. Effect of physical and chemical mutagens on sprouting and survival of corms. Haryana Journal of Horticultural Sciences., 12(1/2), 1-6 (1983a).

Richards, A.J. Plant Breeding Systems. (George Allen and Unwin, London 1986).

Schum, A.R. Mutation breeding in ornamentals: an efficient breeding method? - Acta Horticulturae. 612, 47-60 (2003).

Siavash, H.A., Jirair, C \& Jalil, K. The effects of UV radiation on some structural and ultra structural parameters in pepper (Capsicum longum). Turkish Journal of Biology., 34, 122-25 (2009).

Simard, M.H., Ferriere, N.M \& Silvy, A. Variants of carnation (Dianthus caryophyllus L.) obtained by organogenesis from irradiated petals. Plant Cell, Tissue and Organ Culture. 29, 37-42 (1992).

Singh, K.P., Singh, B., Raghava, S.P.S., Misra, R.L \& Kalia. C.S. In vitro induction of mutation in carnation through gamma irradiation. Journal of Ornamental Horticulture, New Series 2(2), 107-110 (1999).

Singh, R., Goyal, R.K \& Godara, A.K. Effect of gamma radiation on growth, flowering and bulb production in tuberose (Polianthes tuberosa L.) cv. Double. Haryana Journal of Horticultural Science., 40(3-4), 128130 (2011). 
Siranut, L., Peeranuch, J., Arunee, W., Surin, D \& Prapanpongse, K. Gamma ray induced morphological changes in Chrysanthemum. Kasetsart Journal of Natural Sciences. 34, 417-422 (2000).

Sooch, M., Arora, J.S., Singh, K \& Gosal, S.S. Effect of gamma ray irradiation on in vitro multiple shoot formation and establishment of carnation plants. Journal of Ornamental Horticulture, New Series 3(2): 118-119 (2000).

Srivastava, P., Singh, R.P \& Tripathi, V.K. Response of gamma radiation $\left(60^{\circ} \mathrm{C}\right)$ on vegetative and floral characters of gladiolus. Journal of Ornamental Horticulture. 10(2), 135-136 (2007).

Steel, R.G.D \& Torrie, J.H. Principles and Procedures of Statistical Analysis. (McGraw Hill Book Co. Inc. Newyork, USA, pp. 232-251 (1980).

Sutter, E \& Langhans, R.W. Epicuticular wax formation on carnation plantlets regenerated from shoot-tip culture. Journal of the American Society for Horticultural Science. 104, 493-496 (1979).

Wardle, K., Dobbs, E.B \& Short, K.C. In vitro acclimatization of aseptically cultured plants to humidity. Journal of the American Society for Horticultural Science. 108, 386-389 (1983).

Wolff K. RAPD analysis of sporting and chimerism in chrysanthemum. Euphytica 89, 159-164 (1996)

Zalewskam rumin'ska, L.J \& Miller, N. "In vitro" propagation using adventitious bud techniques as a source of new variability in Chrysanthemum. - Sci. Hort., 113, 70-73 (2007).

\section{Abbreviations}

$\mathrm{GA}_{3}$ : Gibberelic acid: MS: Murashige; Skoog's medium BAP: 6-Benzyl amino purine; Gy: Grays; PANBIT: Panoramic Batch Irradiator.

\section{Figures}




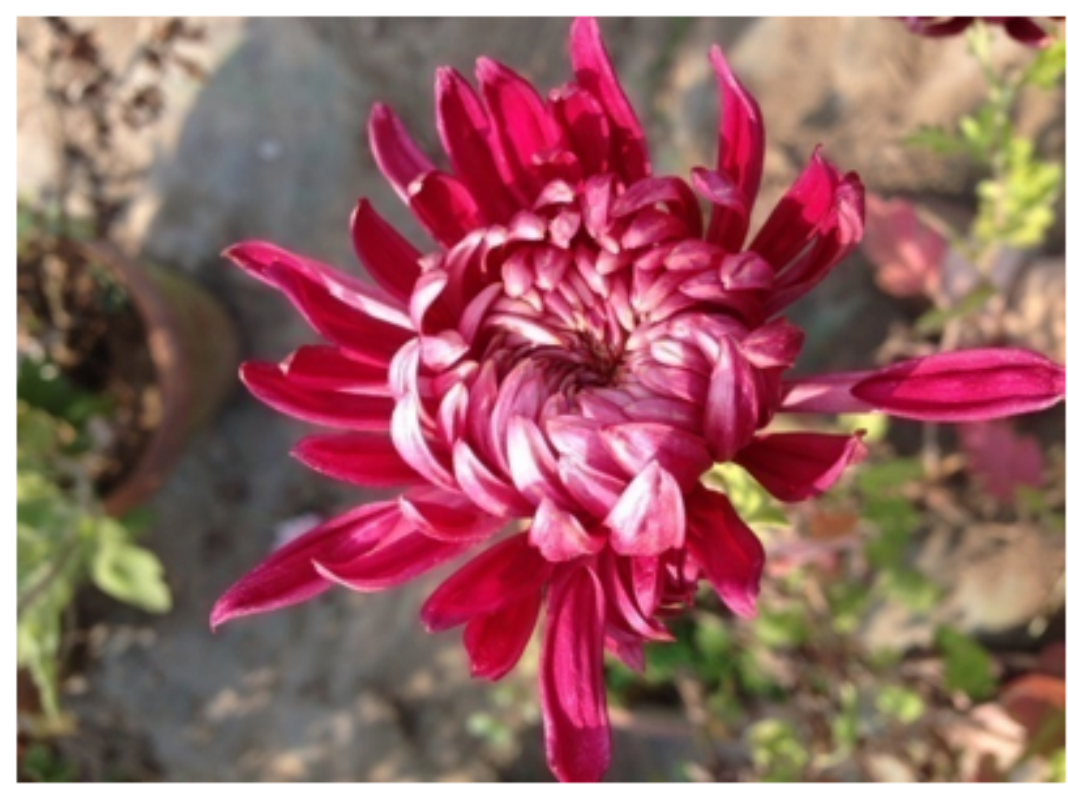

Dendranthemum morifolium L. cv. "Candid"

\section{Figure 1}

Chrysanthemum cultivar selected for the investigation 


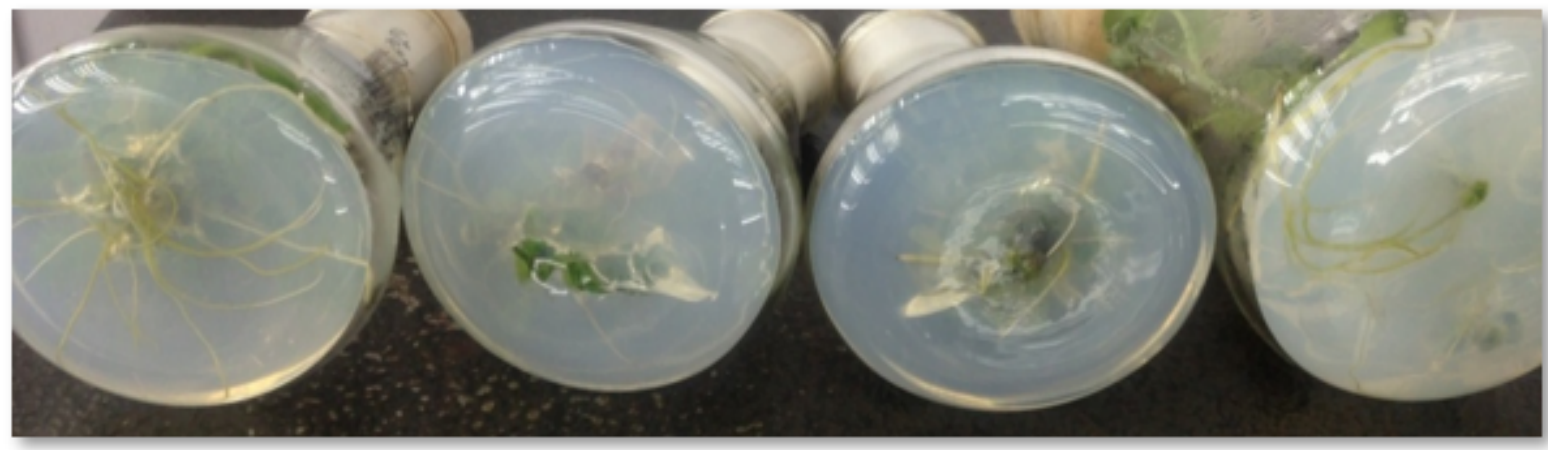

(1)

(2)

(3)

(4)

a) Mass view of rooting

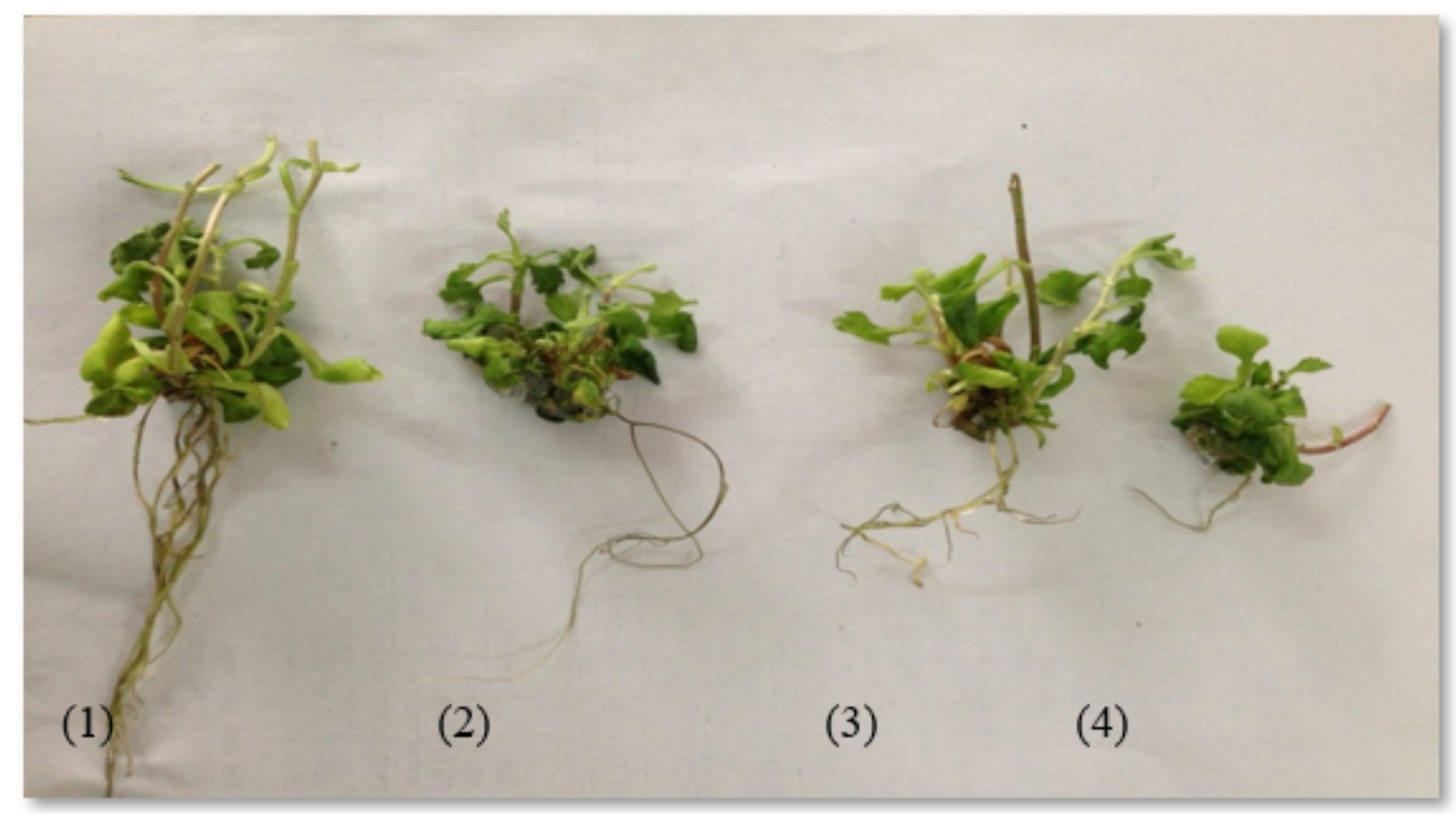

b) Number of roots

${ }^{60} \mathrm{Co}$ gamma irradiation doses :
1) $10 \mathrm{~Gy}$
3) $30 \mathrm{~Gy}$
2) $20 \mathrm{~Gy}$
4) $40 \mathrm{~Gy}$

Figure 2

Rooting of 60 Co gamma irradiated shoots 


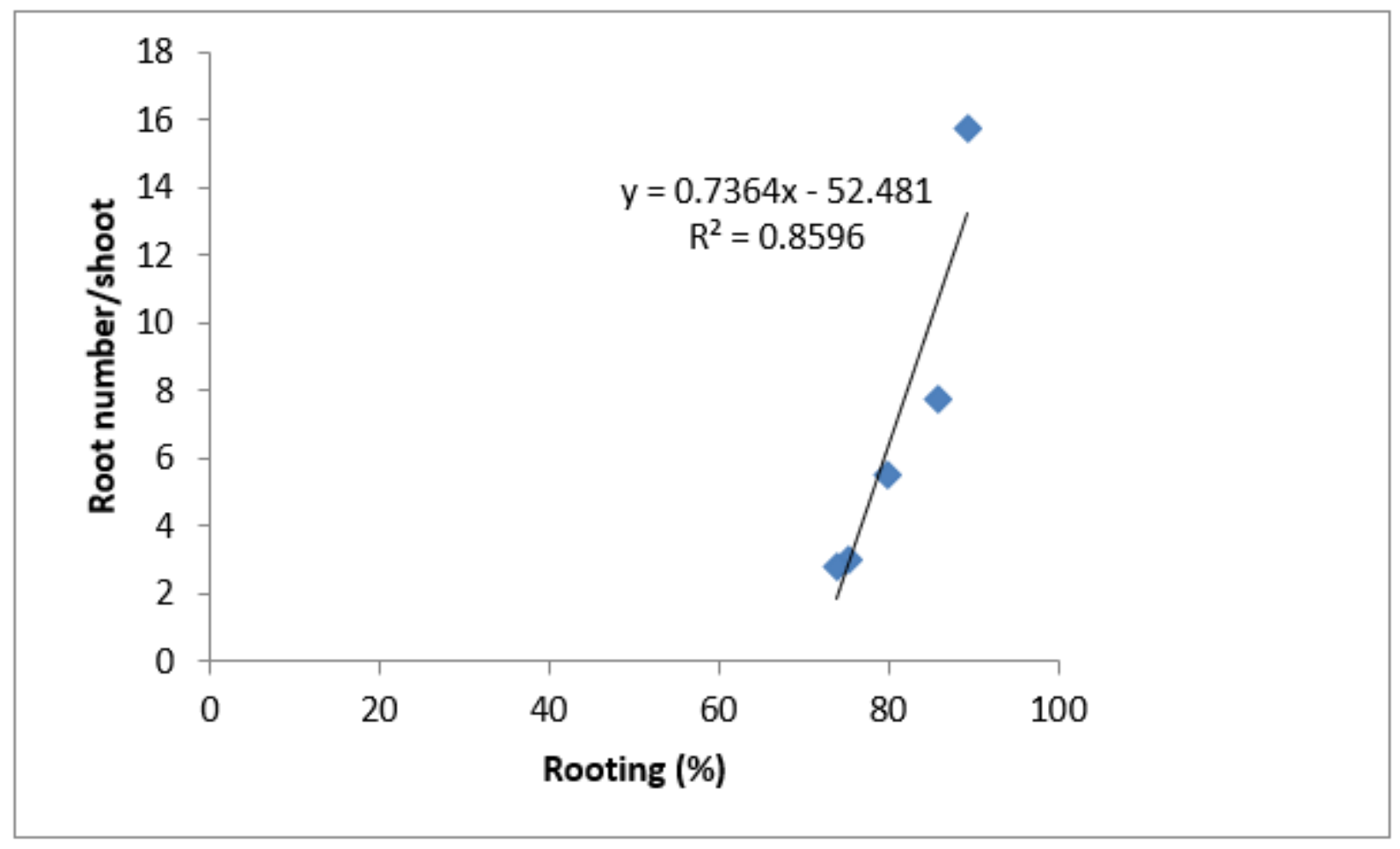

Figure 3

Correlation analysis of Root number/shoot vs Rooting (\%)

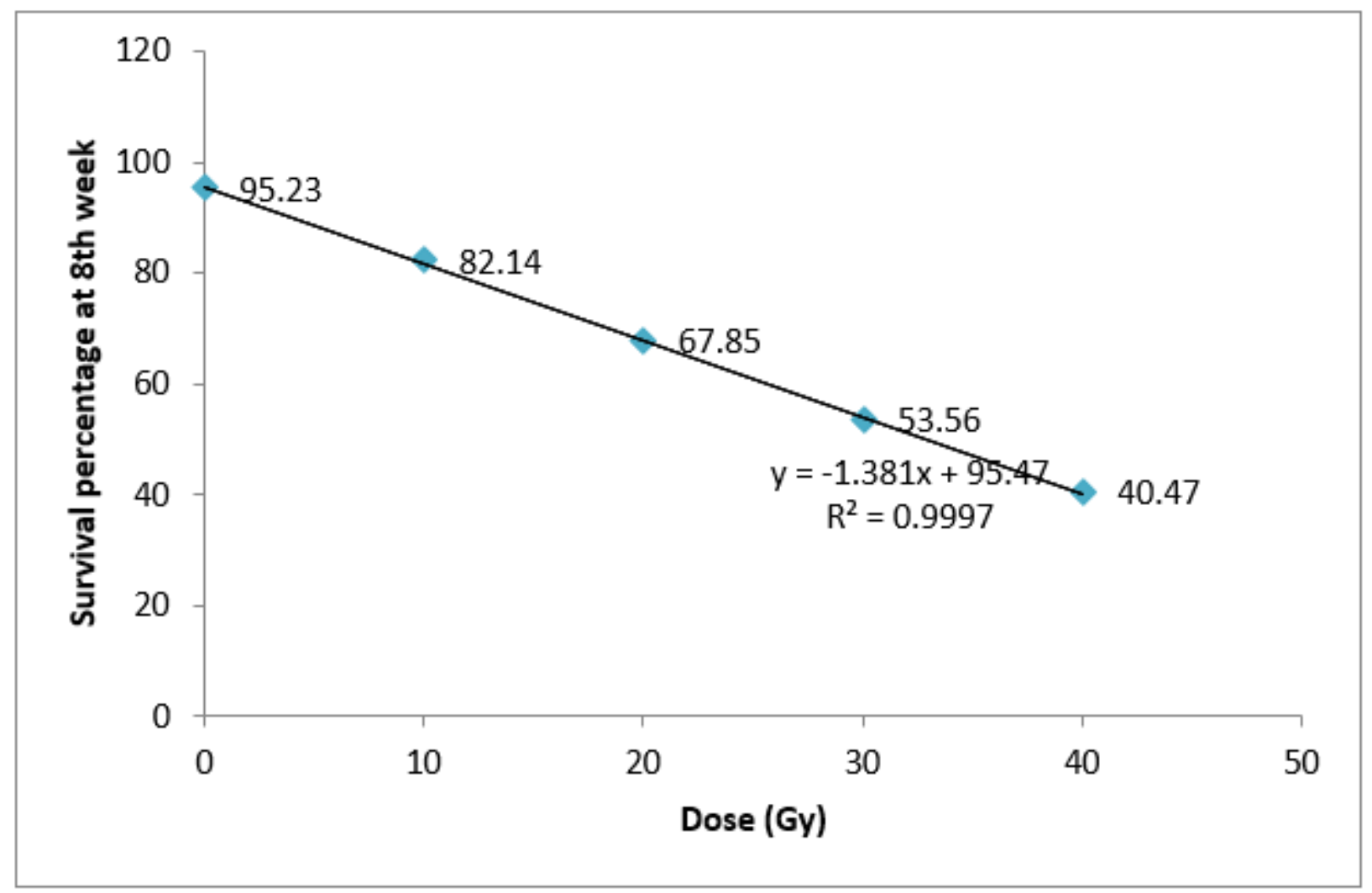

Figure 4 
Correlation of survival percentage with $y$ irradiation dose.

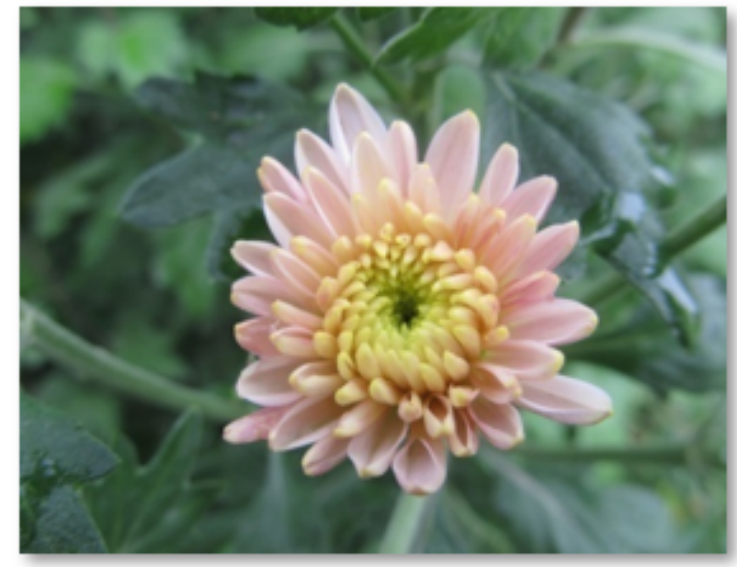

a) Light pink

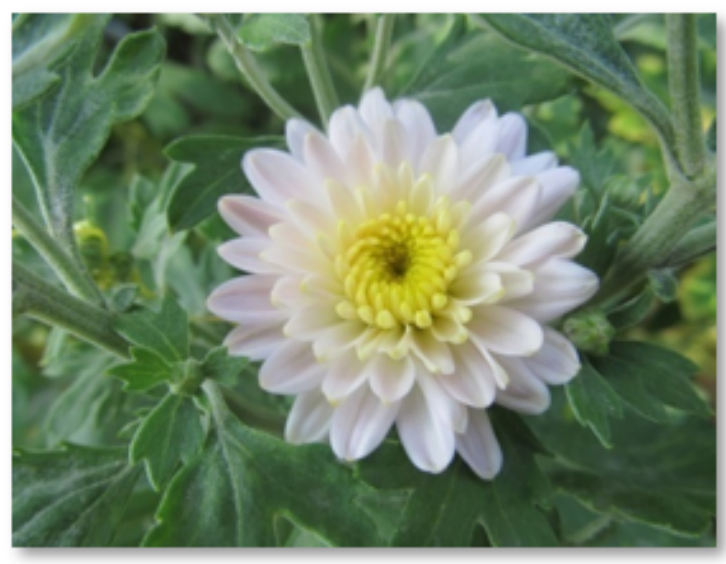

c) White

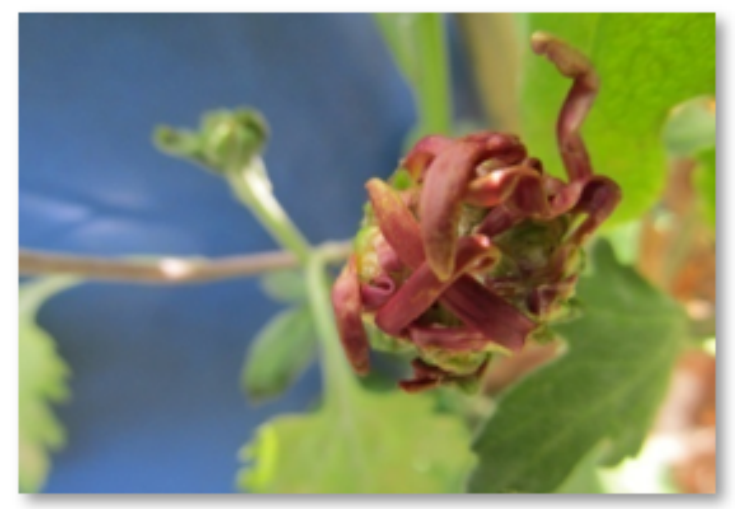

e) Distorted red bud

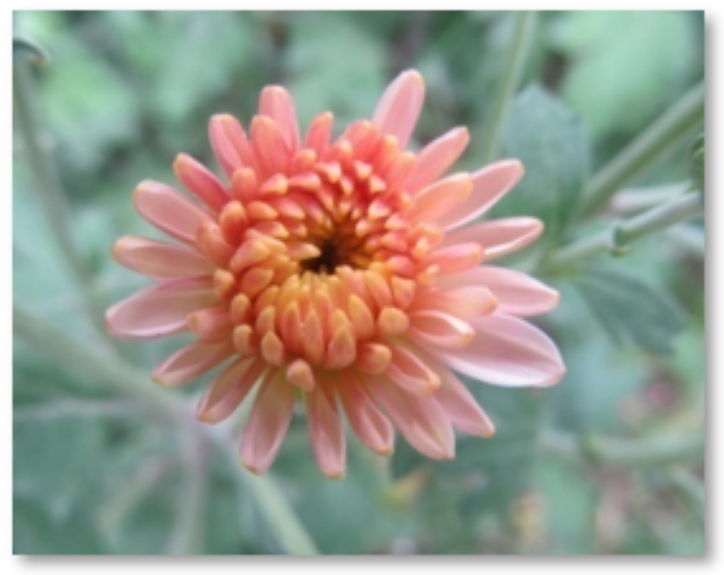

b) Orange pink

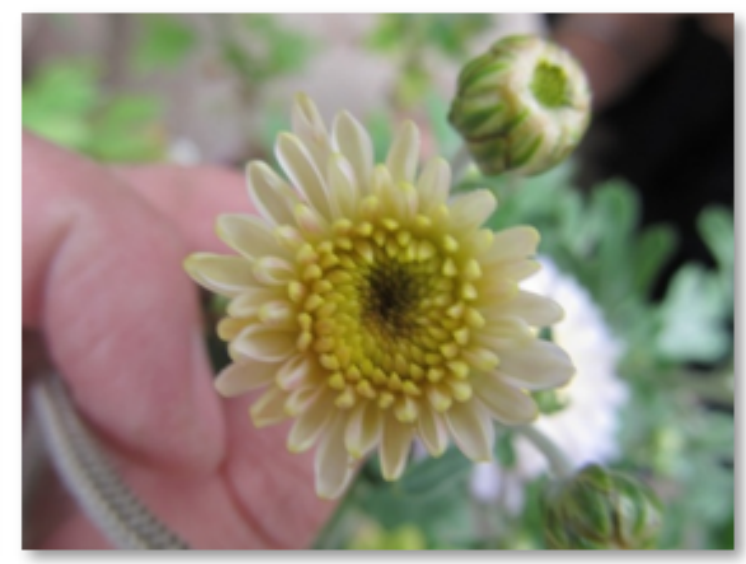

d) Light yellow

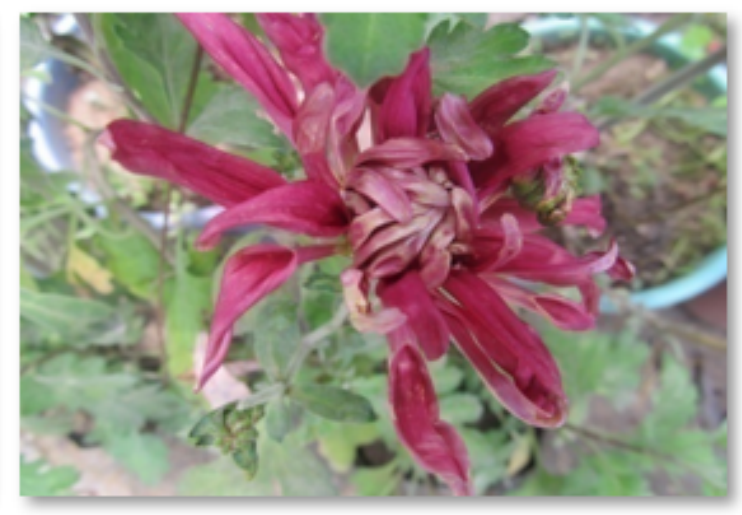

f) Distorted red floret

\section{Figure 5}

Mutants of $60 \mathrm{Co}$ gamma irradiation doses 

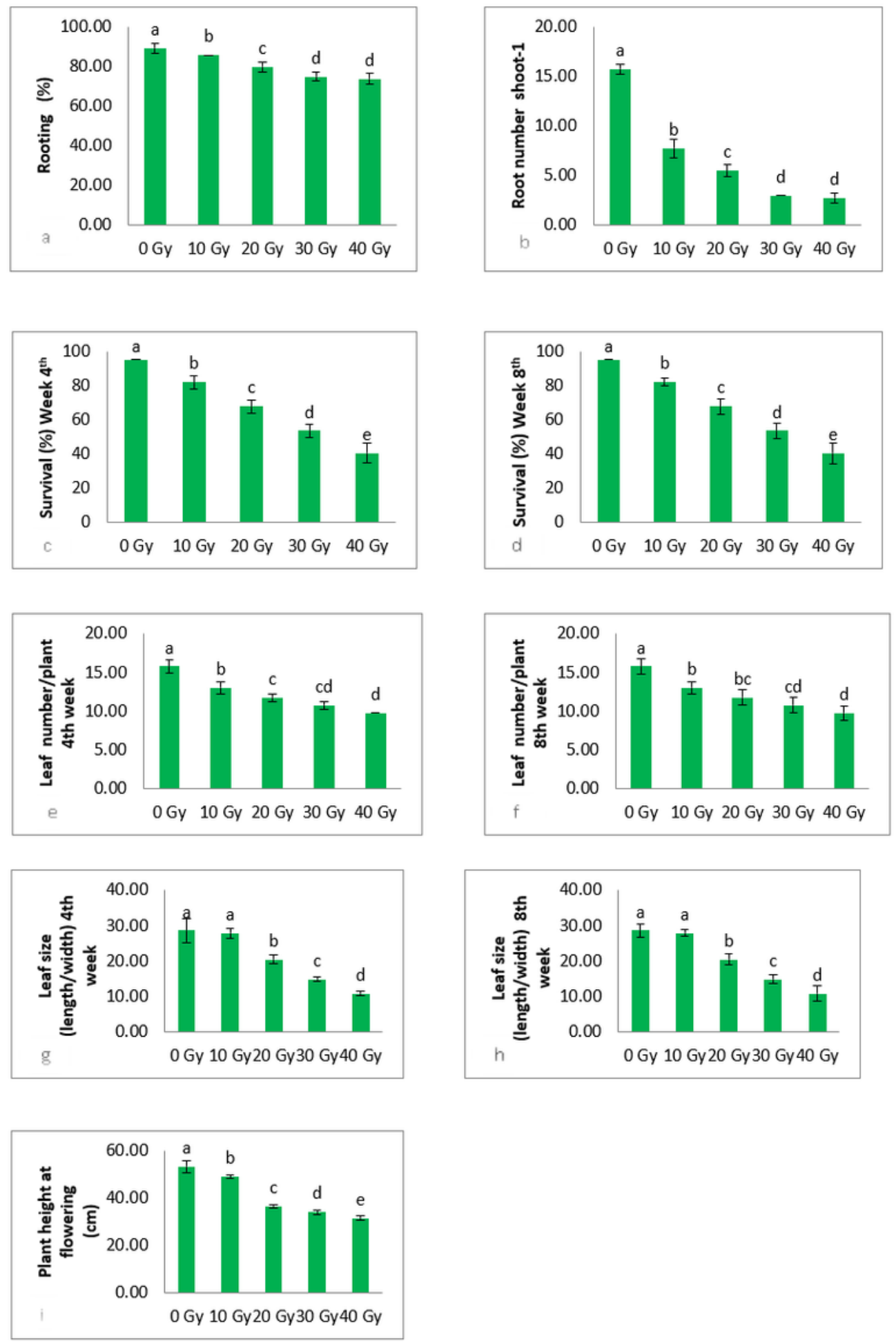

\section{Figure 6}

Influence of $\mathrm{y}$ - rays on a) rooting percentage b) root number per shoot c) survival percentage of rooted shoots at 4th week d) survival percentage of rooted shoots at 8th week e) leaf number per plant at 4th week $\mathrm{f}$ ) leaf number per plant at 8th week g) leaf size per plant at 4th week h) leaf size per plant at 8th week i) plant height at flowering. 